\title{
Primary Clear Cell Carcinoma of Lung
}

\section{Akciğerin Primer Berrak Hücreli Karsinomu}

\author{
Ferit Aslan', Hayriye Ergin Akkoz $^{2}$, Umut Demirci ${ }^{1}$ \\ ${ }^{1}$ Dr A. Y. Ankara Onkoloji Eğitim Ve Araştırma Hastanesi, Tıbbi Onkoloji Kliniği, Ankara, Türkiye \\ ${ }^{2}$ Dr A. Y. Ankara Onkoloji Eğitim Ve Araştırma Hastanesi, Patoloji Kliniği, Ankara, Türkiye
}

doi: 10.5505/aot.2012.99609

Key words: Clear cell carcinoma; Lung

Anahtar Kelimeler: Berrak hücreli karsinom; Akciğer

\section{Sayın Editör,}

Renal hücreli karsinom çoğunlukla berrak hücreli histolojisindedir. Berrak hücreli karsinom (BHK) metastazlarında da ilk akla gelen primerin renal kökenli olduğudur. Nitekim metastatik alanlardan yapılan biyopsilerde de başka malignitelerin BHK varyantları açısından ayırıcı tanısı yapılmadan renal BHK metastazı olarak yorumlanabilir. Hatta bazen immünhistokimyasal incelemeler primer tümör hakkında yol gösterici olmayabilir. $\mathrm{Bu}$ durumlarda ancak klinik ve görüntüleme bulguları patoloji sonuçları ile birleştirildiğinde doğru tanı konulabilmektedir. Bizde ayırıcı tanısını ancak bütün klinik parametreleri kullanarak primer akciğer BHK tanısı alan olgumuzu sunmak istedik.

Elli dokuz yaşında erkek 2 aydır olan sırt ağrıs1 nedeni ile başvurdu. Yapılan fizik muayenesinde performans skoru bir idi, akciğerde bilateral ronküsleri mevcuttu. Özgeçmişinde 40 paket yıl sigara içme öyküsü vardı. Toraks bilgisayarlı tomografisinde (BT) sağ akciğer apeksinde plevra tabanl $166 \times 71 \mathrm{~mm}$ kitle lezyonu saptandı (Resim 1). Batın BT'de patolojik bir lezyon saptanmadi. Periferik akciğer kitlesinden yapılan tru-cut biyopside görünüm öncelikle metastatik karsinomu telkin etmiştir; RCC, TTF-1 ve CK 20 ile boyanma izlenmedi. PAS ile fokal boyanma izlendi (Resim 2). Hastada primer bölgesinin böbrek kaynaklı olduğu yönünde raporlandi. Patoloji sonucu ikinci bir merkezde de renal hücreli karsinomun metastazı olarak yorumlandi.
Hastanın yapılan üst gastrointestinal sistem endoskopi ve kolonoskopisinde malignite lehine bulgu yoktu. Batın BT'de renal kitle görünümü olmaması üzerine istenen PET-BT'de sağ akciğer apeks-üst lob posterior segmentte, kostal plevraya geniş tabanla oturan, gögüs duvarı ile sınırları net ayırt edilemeyen $8 \times 6.3 \times 7 \mathrm{~cm}$ kitle lezyonunda artmış fluoro-deoksiglukoz (FDG) tutulumu izlenirken (SUVm: 8.72), sağ akciğerde birkaç adet milimetrik nodülde ve sol iliak kanatta düzgün sınırlı hipodens lezyonda FDG tutulumu izlenmedi. Tümör lokalizasyonu, büyüklüğü ve görüntülemelerde böbrekle ilgili patoloji ve akciğer dışı başka tutulum olmaması sebebiyle T4N0M0 evre IIIA primer akciğerin BHK's1 olarak kabul edildi. Gögüs cerrahisi tarafindan inoperabl olarak değerlendirilen hastaya definitif kemoradyoterapi başlandi.

BHK histolojisi over, böbrek, endometrium tümörlerinde görülebilmektedir (1). Bunun yanısıra küçük hücre dışı akciğer kanserinin histolojik alt tipi olarak da göz önünde bulundurulmalidir.

Literatürde primer akciğer BHK ile ilgili nadir olgu bildirimleri vardır (2). Dünya sağlık örgütü akciğer kanseri sınıflamasında BHK; adenokarsinom, yassı hücreli karsinom ve büyük hücreli karsinomun bir varyantı olarak sinıflandırılmaktadır (3). Bizde BHK'nın böbrek dışındaki dokularda nadir de olsa görülebileceğini ve akılda tutulması gerektiğini böyle bir olgu ile göstermek istedik. 


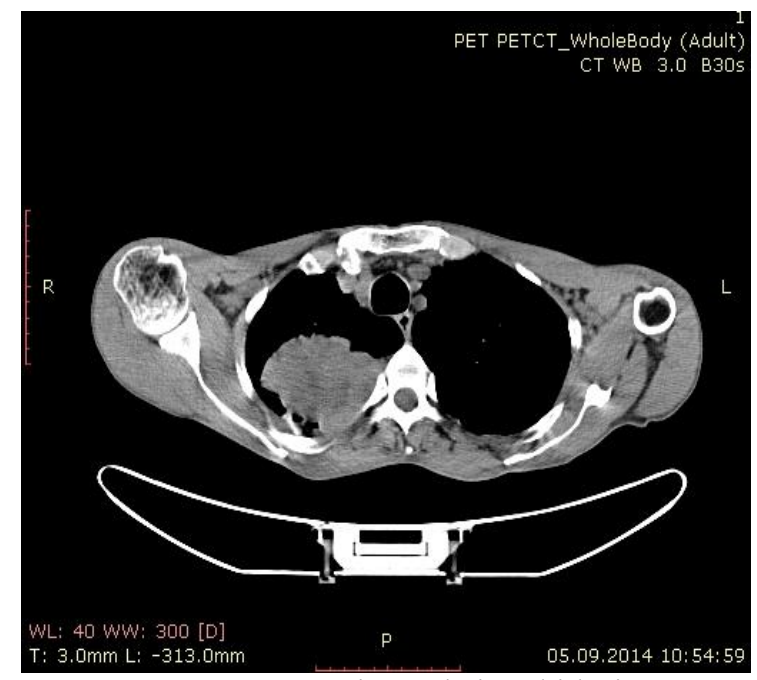

Resim 1: Toraks BT- Primer akciğer kitlesi

\section{Çıkar Çatışması: Yok}

\section{Kaynaklar}

1. Zorn K, Bonome T, Gangi L, et al. Gene expression profiles of serous, endometrioid, and clear cell subtypes of ovarian and endometrial cancer. Clin Cancer Res 2005;11:6422-30

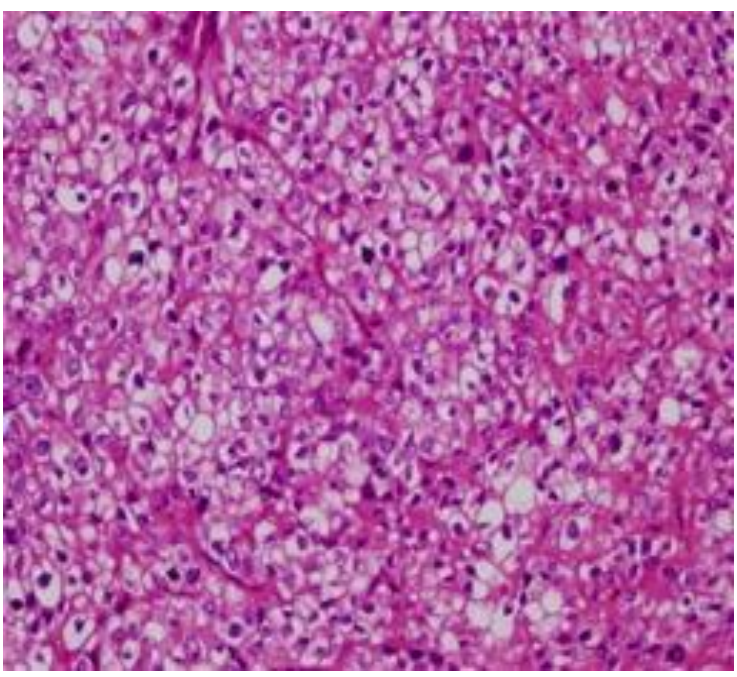

Resim 2: Diffüz şekilde gelișim göstermiş tümör hücrelerinin iri, hiperkromatik nükleuslu, şeffaf sitoplazmalı olduğu dikkati çekmekte ve arada mitotik figürler (x400 büyütme)

2. Kitada M, Ozawa K, Sato K, Hayashi S, Miyokawa N, Sasajima T. Clear cell carcinoma of the lung. Gen Thorac Cardiovasc Surg. 2010;58:87-90

3. Travis, WD, Brambilla, E, Muller-Hermlink, HK, Harris, CC (eds). World Health Organization classification of tumours. Pathology and genetics of tumours of the lung, pleura, thymus and heart. IARC Press. Lyon 200 